\title{
Is there a wall to peek over? Exploring approaches in the science and religion conversation
}

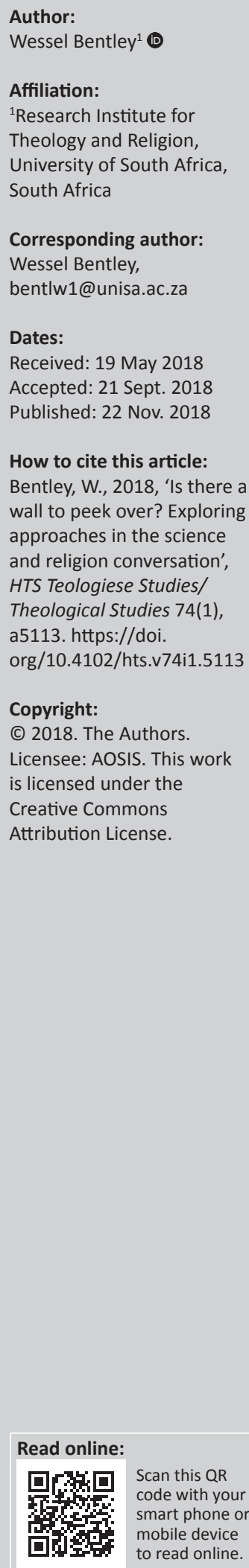

\begin{abstract}
Is there a metaphorical wall that separates science and religion? In the continued interaction between science and religion, the questions of ontology (what is there?) and epistemology (how do we know what is there?) plague efforts to come to an integrated model that successfully includes both partners. In this article, three possible scenarios are discussed: firstly, that science and religion occupy opposite sides of a dividing 'wall'. Secondly, that science and religion stand on the same side of a 'wall' that separates the known from the unknown. Thirdly, the possibility that no 'wall' exists and that science and religion effectively come to interdependent conclusions based on their interaction within an open system. This article addresses the questions of transcendence and immanence against the background of the wall metaphor.
\end{abstract}

\section{Introduction}

The nature of the relationship between science and religion has been well documented. In the past few decades, renowned scholars such as Ian Barbour (1997), John Polkinghorne (2003), John Lennox (2009), Thomas Berry (2009), Wentzel van Huyssteen (2006) and Cornel du Toit (2013) have made profound contributions in addressing this research question. What new can be said about this seemingly tumultuous relationship? Without wanting to re-invent the wheel, this article presents a prolegomena of my own work in this field. It does so by employing a particular metaphor as backdrop in defining the nature of the science and religion conversation. The metaphor stems from an image as follows.

In a popular motivational poster by Imaginary Foundation, ${ }^{1}$ a man is depicted as standing on a ladder, peering over a wall into what seems to be an expanse unlike anything he had seen before. On his side of the wall, everything is in monochromatic shades, with 'this-worldly' debris scattered along the perimeter of his existence. The wall is the end of his world, of his reality. There is no door to pass through. Instead, there is only a window that could offer him a glimpse of the unknown, but it is shut, barricaded like one secures a window from the dangers posed by a raging storm 'outside'. The ladder on which he stands is rickety, curving from side to side as if to suggest that the risk of peering over the wall entails a journey. The journey itself holds the potential to threaten the certainties of his world. Nevertheless, he makes it, having succeeded far enough to be enlightened. He stands in wonder, piously observing 'the other'. The other side of the wall explodes with colour, filled with the potential of space, movement and the dynamic interchange between stars and galaxies. There is nothing 'this-worldly' about the other side. Yet, his world perhaps unbeknownst to him - inadvertently forms part of the greater whole. Next to the man, on the wall, is some text - graffiti - which reads 'The beginning is near'. The difference between 'his world' and the 'world beyond', monochromatic schemes and florescent colour, material mess and cosmic order may seem irreconcilable and distant. The graffiti reminds him (and us) that the difference is only manufactured by the wall, and if one dares, one will find that the beginning of transcendence is closer than we think.

The image suggests that when one is confined fundamentally to the parameters of one's own 'reality', whether be it ideology, world view or methodological approach, this closed reality becomes the source of stagnation and ignorance. The image invites the viewer to consider the potential of what transcendence may bring when one dares to 'peep over the wall' of one's own limited perspective.

This invitation is apt for the science and religion discourse, as one finds that transcendence is more often than not more concerned with breaking through the parameters of one's own perspective

1.A copy of the image can be accessed at https://www.imaginaryfoundation.com/collections/art-prints/products/beginning-is-near-artprint?variant=1906602573845 (viewed 05 January 2018). 
that with pointing to a reality that can truly be considered as beyond the dimensions of physical existence. In a paper entitled 'How postmetaphysical can God-talk be?' (Bentley 2017), I alluded to the daring act of transcending boundaries between the natural sciences, religion and philosophy, specifically when it comes to God-talk. The article proposed that each discipline (science, philosophy and religion) could endorse and enrich their own perspectives, not by clinging frantically to their own vantage points, but by daring to be vulnerable and honestly engaging perspectives other than their own. The point was that engaging other perspectives is less an activity of 'converting other views' than what it is to become enlightened oneself. Now, referring to the image, the question beckons: is there a wall in the science and religion debate that causes a seemingly insurmountable divide between perspectives? The image of the wall itself speaks about the complex relationship between ontology (what is there?) and epistemology (how do we know what is there?). I would like to propose three different approaches that will reflect how science and religion deal with these questions. The first is to propose that there is indeed a 'wall' that separates the ontologies and epistemologies of religion and the natural sciences. The second approach explores the possibility where science and religion find themselves together separated from the common unknown. The third approach proposes that the 'wall' is self-inflicted and that science and religion are in an open system devoid of ontological parameters that deprive us of transcendence.

\section{If there is a wall between science and religion}

On a simplistic level, this approach describes a radical modernist divide between science and religion, where it is believed that science and religion are occupied with two nonintersecting methodologies of 'truth-seeking'. Perhaps the most prominent academic description of such an approach is found in Gould's non-overlapping magisteria (NOMA) (Gould 2002). Gould suggests that both science and religion seek to address core issues, but approach these from very different perspectives. He admits that the potential is created for science and religion to battle it out until one perspective is vindicated at the cost of the other's downfall (Gould 2002:52). The remedy, he suggests, is a dialogue which recognises the autonomy of both science and religion on epistemological grounds. His suggestion entails science and religion respecting that each other's methodological, epistemological and ontological presuppositions are unique to their respective fields and to treat them as truths held within these spheres. As the discourse unfolds, each perspective may be influenced by the other and therefore spark adaptations within the other's understanding, while still maintaining their own domains without truly intersecting (Gould 2002:134-137). The 'wall' in this case is the defining boundaries of the epistemological scope of both science and religion.

The theme of boundaries is further explored in what Gregersen (2013b) describes as 'dermal metaphysics'. It is a perspective which he critiques but describes as the delineating borders of what a specific discipline may hold as truth according to their own ontological and epistemological foundations. Gregersen notes that 'dermal metaphysics' works in theory, but when interrogated, one finds that the liminal space between what is within the confines of the dermis and that which is regarded as being 'other' is not as rigid as what the metaphorical wall would suggest (Gregersen 2013a:260).

In the practical outworking of the dialogue between science and religion, however, there are definite instances where the 'wall' is indeed very rigid and firm. On the side of science (and this is not a universal approach), the rise of the New Atheists under the lead of Richard Dawkins, Daniel Dennett and Christopher Hitchens suggests that only science is concerned with finding real truth, while religion dabbles in fairy tales. Not only is there a wall for them between scientific truth and religious superstition, but there should actually not even be an attempt to engage the other, for an attempt by science to learn anything of scientific value from religion would be a futile exercise. While Gould made some attempt for interaction, even in the delineating of boundaries between science and religion, Dawkins rubbishes NOMA as an attempt to suggest that science and religion (although on different sides of a wall) exist as equals, albeit having very diverse approaches to truth-seeking (Dawkins 2006:77-80). The separation is clear in Dawkins' mind: Religion has nothing to teach science, while science has the full right to critique religion's premise of God's existence and all other faith claims, as science is the only credible way in which we can come to a position of truth (Dawkins 2006:78).

On the side of religion, and in this case Christian literalism, the wall is equally solid. Despite any attempt to prove otherwise, there are Christian fundamentalists who will maintain that the Earth is 6000 years old, who will dispute the theory of evolution by holding to a creationist argument or believe that Methuselah lived to be almost 1000 years old. From this perspective, science is always subject to universal truths as revealed in Scripture.

Between the New Atheists and Christian literalists, and to a lesser extent NOMA and dermal metaphysics, this model divides opposing world views and epistemologies. Specifically, in the case of the New Atheists and Christian literalists, the wall becomes the foundation for the creation of fundamentalism - on both sides of the science and religion divide. Such fundamentalism creates an acrimonious relationship between science and religion. The wall (the delineated boundary of each perspective) is merely the assumption that the other is ignorant in light of the absolute certainty of one's own position.

Using the metaphor, one can imagine Benny Hinn and Richard Dawkins standing on either side of the wall, not in conversation, but as bad neighbours insulting one another while throwing the debris from their own sides at each other. 
Needless to say, the science and religion conversation cannot and will not move forward using this approach. If the wall is the dogged clinging to epistemology, then what does transcendence mean in this context?

Transcending the wall or 'peeping over the wall' is not to be enlightened, but the attempt to disprove the opposition. This is done while ignoring two points: firstly, the sterility of their own position when it stands on its own. For fundamentalist science, the blind spot is the assumption that epistemology depends purely on observation, repetition and predictability, while religion errs towards depending exclusively on revelation or divine insight. When used mutually exclusively, science cannot appreciate the value of religious 'imagination', while religion cannot appreciate that some aspects of reality once ascribed to God may, in fact, have a more 'this worldly' explanation. Secondly, neither position will acknowledge the potential growth it will bring to their own world when they dare to extract some truths, however minimal it may be, from the other side.

\section{What if science and religion stand on the same side of the wall?}

In a second model, the boundary is not between science and religion, but is the wall that encompasses the reality of our own common knowledge separated from the unknown. Using another metaphor, Marcelo Gleiser (2014) refers to the island of knowledge. He suggests that the image of an island can be used to represent knowledge, while the ocean surrounding the island represents what is not yet known. As the tides rise and fall, the beach at times expands into the ocean, while at other times surrenders much of itself, and so knowledge gains ground into the unknown, while occasionally having to retract its certainties because of the process of (unsuccessful) knowledge verification. The point in this image is that knowledge should be perceived as 'common property' (Gleiser 2014:xxii), even between science and religion. Science and religion occupy the same space of what is known, while the unknown (or not yet discovered) infinitely surrounds our reality.

Here, the wall is the parameter of our combined knowledge systems. If knowledge (or information) determines the limits of our reality, then as Barry Allen, the Canadian philosopher, suggests, knowledge and truth fall squarely within the ambit of the reliability of information (Allen 1997:9-12). We can trust our reality because our knowledge of it is reliable, whether it has a scientific or religious origin. Reliability is therefore the boundary. The other side of the wall is threatening because it is not predictable. But there is something innately inquisitive in our search for knowledge beyond our own limitations. One of the benefits of this transcending nature, Allen suggests, is our 'this worldly' venture into ethics, which refers to our capacity to imagine the intangible 'what ought to be' with the aim of appropriating it for our side of the wall (Allen 1997:8). The very act of generating knowledge is transcendental (Allen 1997:19-20), moving boundaries, for the wall becomes dynamic and is not as rigid as in the previous model. To use Gleiser's image, the use of imagination in venturing over the parameters of our knowledge and knowledge systems into the 'unknown' is the reshaping of the liminal space that separates the beach from the ocean.

Here, transcendence is the common human path, holding the tension between the 'certainties' of what we know while celebrating the potentialities of the unknown. Transcendence means to rise above the limitations of our epistemologies in order to get a different perspective, not only for the sake of reinforcing our own fundamentals, but also daring to explore the potential of what could be. To transcend means to explore, to imagine and to follow intuition (see Du Toit 2011). For the time being, we can only know what we know, and what we know is described using a particular hermeneutic of interpreting that which is, while catching 'this worldly' glimpses of what could be.

While standing on the same side of the wall, there are still some dangers that need to be acknowledged. Religion runs the risk of being transcendentally fixated, while the natural sciences may stare at the immanent reality of 'this side of the wall', sometimes at the expense of not taking note of the transcendental. Schacht notes this danger and suggests that although science and religion may occupy the same reality, they struggle to be conversation partners as religion may interpret 'reality' using metaphysical propositions that may not be acceptable to the interpretations of empirical science (Schacht 1997:84). Clayton similarly argues that if science and religion were fixated on these respective realities (this side and that side of the wall), the only way in which they can cope with existing on this side of the wall would be to adopt either agnosticism (for science) or fideism (for religion) as their ontological and epistemological frameworks (Clayton 2011:17-20). Science, concerned with finding truth only on this side of the wall, would not be concerned with God, metaphysics or non-tangible imaginings, while religion would interpret everything through the lens of faith. Despite this dilemma, this model presents the possibility for a more common approach in interpreting and understanding existential reality.

While this approach is substantially more helpful than the first one, it does not satisfactorily answer the following questions: how do we determine whether the information of our reality is indeed reliable? Which methodology do we use? How do we determine ontological 'truth' - is it by observation or do we need to exercise a certain measure of faith? Is this where science and religion intersect or cooperate? Theoretically, the image sounds enticing, but the reality of exploration is that in our common quest for 'truthseeking', we are still confined by reliability epistemologies that leave science and religion on different paths 'on this side of the wall'. 


\section{What if there is no wall at all?}

What if we were to suggest that no wall actually exists either between science and religion or between our knowledge and ignorance? What if there was no wall between our certainties and the unknown, but instead we are faced with a hazy fog that prevents us from seeing clearly beyond our current 'reliable information'? What if we stand with an openness towards the future with all its potential, inevitably approaching it, whether it be from vantage points that have scientific or religious ontological and epistemological foundations? This is the view held by McGrath in his recent publication, Re-imagining Nature (McGrath 2017), by Van Huyssteen in his post-foundational approach (Van Huyssteen 1997), and in Nürnberger's description of God as the 'Transcendent (yet immanent) source and destiny of reality' (Nürnberger 2016:2-119). Here follows a brief summary of their arguments:

\section{McGrath}

McGrath points out that science and religion are to be understood as social constructs. Each of these social constructs has dedicated disciplines that effectively become wall builders - creating unnecessary divisions between methods of truth-seeking (McGrath 2017:2). Of course, as a theologian, McGrath sees the relationship between science and religion from the perspective of religion. He does not claim to speak on behalf of science, but speaks about religion (Christian theology in particular), and about the role it can play in a world where scientific epistemology is held as the preferred instrument in determining 'truth'.

To McGrath, religion's engaging with science is through what he terms 'Natural theology'. Being cognisant of the fact that 'Natural theology' carries with it a history of Christian understanding, McGrath is quick to define the term to suit his usage thereof. Shying away from a pantheistic approach, where nature is exclusively used to come to an understanding of God, McGrath opts for a perspective that suggests that Natural theology is the religious person's ability to see nature in a new light. It is not necessarily a religious light, but the light of holding together faith convictions and scientific discovery without needing to surrender either in favour of the other. On the part of the religious person, it requires an openness to the possibility that the realm of physics and all that is discovered by science may challenge faith assumptions previously held as truth, but it does not destroy the core of these faith convictions. Let me illustrate. At one point, it was believed that the sun revolves around a flat, discshaped earth. This was the standard Christian approach to cosmology, endorsed by Scripture (particularly the Gn 1 creation narrative) and forming the foundation for how it was understood that God created all things. Copernicus' discovery of the earth spinning around its own axis and, in turn, around the sun, of course, caused a stir in religious circles. But science did not destroy religion; instead, religion was able to appreciate its own convictions in light of new truths (McGrath 2017:24-25). The religious observer is able to appreciate both nature and God anew - not as mutually exclusive entities, but where nature (and by default all the laws of physics) and God (with all metaphysical presuppositions) are part of a metanarrative, unfolding the truths of the system of which we form part.

The mistake humanity makes by defining a delineated parameter either between physics and metaphysics or between science and religion is by assuming that we are able to objectively engage with these fields or perspectives. If humanity is indeed capable of observing objectively, then rightfully it could assume the authority of distinguishing between truth and untruth, adding the perception that it can hold to what are fundamental certainties. It would then be easy to erect a wall between what is known and what is not known, between disciplines, perspectives and beliefs. McGrath reminds us that we are not objective observers, but that we are merely interpreters (McGrath 2017:78-104). Science interprets its observations using methodologies that are congruent with its epistemological frames of reference. Religion, in turn, interprets its observations using its epistemological methodologies founded in faith traditions. Both would fall into the trap of fundamentalism if they were to assume that their epistemological frameworks were exhaustive and capable of making universal declarations of fact. Rather, science and religion as interpreters form part of a 'community of interpreters' (McGrath 2017:97), standing in an open system, speaking to one another about what they see and how they interpret it. In this open system, religion gains insights from science and can interpret and reinterpret its faith convictions in light thereof. In turn, religion offers science the gift of an 'imaginarium' (McGrath 2017:158-163) - an image of how the physical nature that science investigates forms part of a metanarrative of cohesion, belonging, relationship, community, purpose, mystery and hope. To McGrath, it is this imaginarium that subverts attempts by scientism to build a wall and to lock out religion from any claims to truth-seeking (McGrath 2017:156-162).

\section{Van Huyssteen}

Van Huyssteen's post-foundational approach suggests a similar blurring of the lines between disciplines while moving into common, open spaces. Congruent with McGrath's argument of being a community of interpreters, Van Huyssteen advocates a position which points to our existence in one - for lack of a better term - reality. Science and religion do not exist in separate realities, but exist in the same open system, while holding to their ontological and epistemological foundations (Van Huyssteen 1997:1-5). In this light, we must remember that persons, embodied persons at that and not discipline-specific ontologies or epistemologies, form the locus of our experience of reality (Van Huyssteen 2006:10). The scientific and religious ontologies and epistemologies are tools that these embodied persons use to try and understand this experience of being. 
Our natural inclination in any search for truth is to establish foundations. Foundationalism - the dogged clinging to ontological and epistemological foundations - builds walls, very similar to the first and second scenarios described in this article. In an attempt to move away from foundationalism, disciplines may be tempted to migrate to non-foundationalism, denying 'that we have any of those alleged strong foundations for our belief-systems and argue instead that all our beliefs together form part of a groundless web of interrelated beliefs' (Van Huyssteen 1997:3). The conclusion to this, Van Huyssteen argues, is fideism, which blindly engages with other perspectives while ignoring the roots of its own or of the other (Van Huyssteen 1997:3-4). Post-foundationalism is not nonfoundationalism. Post-foundationalism values two principles: appreciating context (including foundational ontologies and epistemologies) and transcendent creativity (that a discipline's own context is not enough but needs other perspectives for a more comprehensive engaging with reality) (Van Huyssteen 1997:4).

One can deduce that for Van Huyssteen, foundationalism and non-foundationalism are both expressions of bad religion and poor science. For embodied persons to make sense of their being and context, they need to be able to present 'good reasons' (Van Huyssteen 1997:260) for their interpretation of their realities. It is neither good science nor responsible religion simply to have some reasons for foundational truth statements; one must have the 'strongest and best available reasons to support the rationality of one's beliefs within a concrete context' (Van Huyssteen 1997:260). At times, the answers will be found in intersections between science and religion (where they both agree), while at other times, either of these will be able to offer more meaningful responses on their own. The embodied person is not expected to choose between science and religion, but existing within an open system, they can find a meaning in either or in both, fully accepting and appreciating their ontological and epistemological foundations and applying it to their lived experience.

\section{Nürnberger}

Klaus Nürnberger calls this interpretation of lived experience 'Experiential realism' (Nürnberger 2016:47-55). 'It tries to understand how the reality that we experience is actually put together, how it actually functions and how it can be transformed and utilised to our advantage' (Nürnberger 2016:51). Nürnberger, who relies on emergence theory, suggests that the open complexity of God as the source and destiny of reality manifests in our experience of being and can be appreciated using all the 'instruments' at our disposal (Nürnberger 2010; 2016:50). God, in this sense, is not to be reduced to a 'force', 'power' or deity, a person outside the realm of physics. This would be the god of deism (Nürnberger 2016:15). God, in Nürnberger's understanding, is immanently transcendent: the origin, culmination of and aim of reality, on all levels of complexity. Science and religion have a role to play in gaining an understanding of being in this open system of complexity. The aim of science for Nürnberger is nevertheless not to be a theological tool or to prove God's existence, but to appreciate the 'all' theologians proclaim to have come into existence through God (Col 1:16). In his mind, science and religion hold hands, mesmerised by the mystery of being and becoming, not having attained any absolute truths from their own perspectives, but venturing into the experience of lived reality with an innate inquisitiveness.

Listening to McGrath, Van Huyssteen and Nürnberger, what does transcendence mean? In this model, transcendence starts with becoming vulnerable in the midst of the expanse, both for science and religion, engaging with the experience of life from the perspective of no " essential" core, other than an engagement with the question of our relationship with nature and the divine or transcendent' (McGrath 2017:7). We acknowledge that as Thomas Nagel indicated, 'every viewpoint is actually a "view from somewhere"' (McGrath 2017:27; Nagel 1989:67-89), and thus our reality remains intact without getting lost in epistemological hypotheticals. As Hick suggests, the measure of transcendence is not locked up in what we perceive to be other-worldly, but is the essence of the experience of existence in light of the expanse. There is always something to aspire to - perhaps to move away from the banalities of life - and hence religion or science without transcendence is an elitist position (Hick 1997:46-47). It is locked into its own system and soon becomes ignorant, irrelevant and sterile. A critical realism is necessary as we cannot know what it is to transcend, but we know that our present existence is influenced by that which is 'more than here' and is drawn to it (Hick 1997:51).

\section{Conclusion}

This article argued that there are three possibilities for the science and religion conversation. Perhaps there has been a natural progression from one to the other. While there is a wall between science and religion, no progress can be made and transcendence is mutually destructive for both these disciplines. When science and religion stand on the same side of the wall, the conversation might be hampered by religion's fixation on the metaphysical while science focusses on the physical. If the wall is removed, then the potential is created for the science and religion conversations to truly partner meaningfully in appreciating 'what is' while daring to venture into the 'what could be'.

The graffiti 'The beginning is near' is encapsulated in Levinas' 'the ontology of sameness' (Cohen 1986:7). The wall may create the illusion that 'the other', whether be it other perspectives, or the other of the unknown, is a threat best kept out of our reality by the barricading of windows, leaving us to occupy the safe spaces of ignorance. But this ignorance quickly becomes monochromatic, filled with the debris of used certainties. The risk of journeying beyond my space, no longer giving power to the confining parameters of certainty, but exploring the misty openness of the unknown and yet to be discovered, suggests that transcendence is closer than we may think and that indeed 'The beginning is near', only a 
step away. The threat is diffused by responsible enquiry, which takes into consideration the perspectives of varied conversation partners, including science and religion.

The 'beginning', the reality of the perceived 'this side' and 'that side', cannot be the exclusive domain of either religion or science. It is a reality and mystery best and responsibly explored together, holding theontological and epistemological foundations of both in hand, acknowledging that experienced reality is not bound in either, but appreciated by both.

\section{Acknowledgements Competing interests}

The author declares that he or she has no financial or personal relationships which may have inappropriately influenced him or her in writing this article.

\section{References}

Allen, B., 1997, 'The ambition of transcendence', in D.Z. Phillips \& T. Tessin (eds.) Religion without transcendence?, pp. 7-24, Macmillan Press, London.

Barbour, I.G., 1997, Religion and science, HarperOne, San Francisco, CA.

Bentley, W., 2017, 'How postmetaphysical can God-talk be?', HTS Theological Studies 73(3), 1-7. https://doi.org/10.4102/hts.v73i3.4669

Berry, T., 2009, The sacred universe: Earth, spirituality, and religion in the twenty-firs century, M.E. Tucker (ed.), Columbia University Press, New York.

Clayton, P., 2011, The predicament of belief: Science, philosophy, faith, Oxford University Press, Oxford.

Cohen, R.A., 1986, 'Introduction', in R.A. Cohen (ed.), Face to face with Levinas, pp. $1-12$, SUNY Press, New York.
Dawkins, R., 2006, The God delusion, Bantam Press, London.

Du Toit, C.W., 2011, 'Shifting frontiers of transcendence in theology, philosophy and science', HTS 67(1), 1-10.

Du Toit, C.W., 2013, 'A scientific defence of religion and the religious accommodation of science? Contextual challenges and paradoxes', in C.W. Du Toit (ed.), Knowing, believing, living in Africa: Perspectives from science and religion, pp. 1-19, Research Institute for Theology and Religion, Pretoria.

Gleiser, M., 2014, The island of knowledge: The limits of science and the search for meaning, Basic Book, New York.

Gould, S.J., 2002, Rocks of ages: Science and religion in the fullness of life, Ballantine Books, New York.

Gregersen, N.H., 2013a, 'Deep incarnation and kenosis: In, with, under, and as: A response to Ted Peters', Dialog 52(3), 251-262. https://doi.org/10.1111/ dial.12050

Gregersen, N.H., 2013b, 'God, information and complexity: From descriptive to explorative metaphysics', Theology and Science 11(4), 394-423. https://doi.org/1 $0.1080 / 14746700.2013 .866475$

Hick, J., 1997, 'Transcendence and truth', in D.Z. Phillips \& T. Tessin (eds.), Religion without transcendence?, pp. 41-59, Macmillan Press, London.

Lennox, J.C., 2009, God's Undertaker: Has science buried God?, Lion Books, Oxford.

McGrath, A.E., 2017, Re-imagining nature: The promise of a Christian natural theology, Wiley-Blackwell, Oxford.

Nagel, T., 1989, The view from nowhere, Oxford University Press, New York.

Nürnberger, K., 2010, 'Immanent transcendence and radical transcendence: The pivotal issue between a Christian theology and a naturalistic metaphysic', in C.W. Du Toit (ed.), Homo Transcendentalis? Transcendence in science and religion, pp. 103-127, Research Institute for Theology and Religion, Pretoria.

Nürnberger, K., 2016, Faith in Christ today: Invitation to systematic theology, vol. 2, Cluster Publications, Pietermaritzburg.

Polkinghorne, J., 2003, Belief in God in an age of science, Yale University Press, London.

Schacht, R., 1997, 'After transcendence: The death of God and the future of religion', in D.Z. Phillips \& T. Tessin (eds.), Religion without transcendence?, pp. 73-92, Macmillan Press, London.

Van Huyssteen, J.W., 1997, Essays in postfoundationalist theology, William. B. Eerdmans Publishing Company, Grand Rapids, MI.

Van Huyssteen, J.W., 2006, Alone in the world? Human uniqueness in science and theology: The Gifford lectures, William B. Eerdmans Publishing Company, Grand Rapids, MI. 